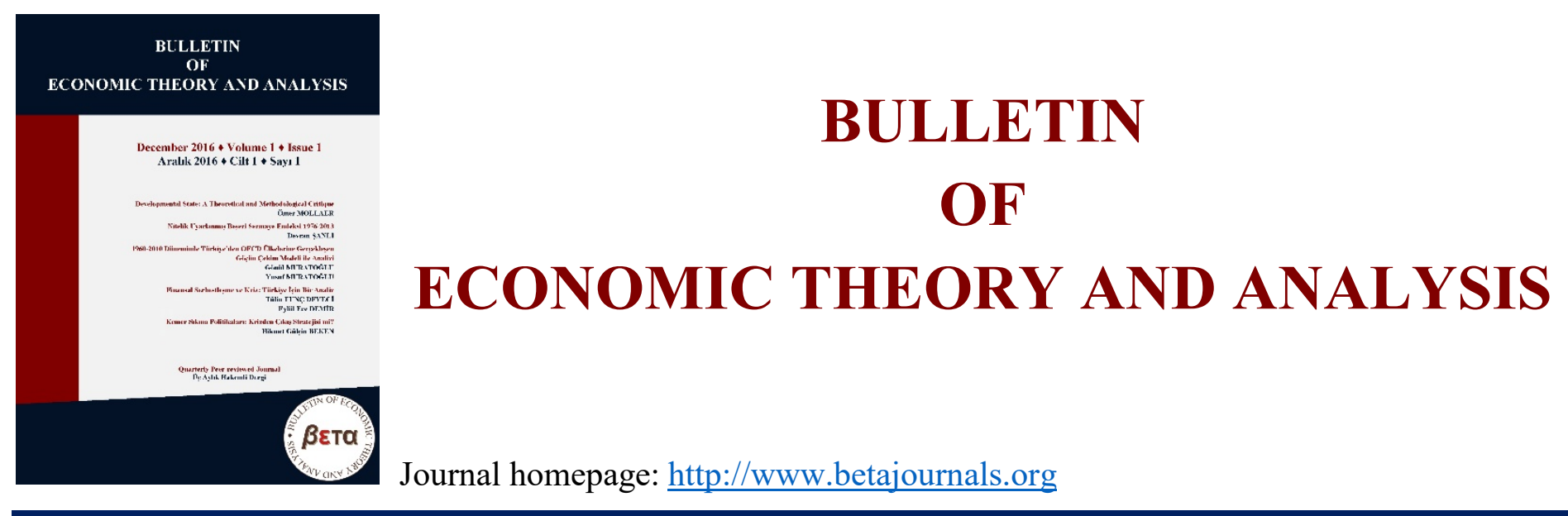

\title{
Asymmetric Relationship between Institutional Quality and Remittance Inflows: Empirical Evidence for Turkey
}

\section{Şerife Özşahin \& Gülbahar Üçler}

To cite this article: Özşahin, Ş. \& Üçler, G. (2017). Asymmetric Relationship between Institutional Quality and Remittance Inflows: Empirical Evidence for Turkey. Bulletin of Economic Theory and Analysis, 2(3), 189-204.

Received: 6 Aug 2017

Accepted: 11 Nov 2017

Published online: 29 Nov 2017

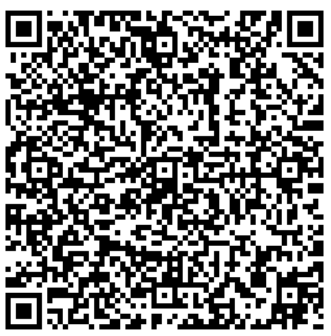




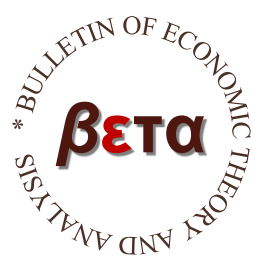

\title{
Bulletin of Economic Theory and Analysis
}

Volume II, Issue 3, pp. 189-204, 2017

http://www.betajournals.org

\section{Asymmetric Relationship between Institutional Quality and Remittance Inflows: Empirical Evidence for Turkey}

\author{
Şerife Özşahin ${ }^{\mathrm{a}}$ \\ Gülbahar Üçler ${ }^{b}$
}

a Assistant Professor, Necmettin Erbakan University, Faculty of Social Sciences and Humanities, Department of Economics, Konya, TURKEY

b Assistant Professor, Ahi Evran University, FEAS, Department of Economics, Kırşehir, TURKEY

\begin{abstract}
This study aims to examine the asymmetric causal relationship between the institutional quality index and remittance inflows in Turkey using the monthly data for the period between January 1985 and December 2014. To this end, the institutional quality index is formulated based on the eight different institutional quality indicators released by ICRG (International Country Risk Guide). Stationarity analyses of the variables are conducted with the LM two structural breaks unit root test developed by Lee and Strazicich (2003), while the existence of asymmetric causal relationship is examined with Hatemi-J (2012) asymmetric causality test. The findings obtained from the asymmetric causality test reveal that the improvement in the level of institutional quality does not affect remittance positively, whereas negative shocks in the level of institutional quality cause a negative shock in remittance inflows.
\end{abstract}

Keywords

Remittance Inflows, Institutional Quality, ICRG, Hatemi-J (2012) Asymmetric Causality Test

JEL Classification F24, O53, C22

CONTACT Şerife ÖZŞAHIN $\bowtie$ sozsahin@konya.edu.tr $\biguplus^{\circ}$ Assistant Professor, Necmettin Erbakan University, Faculty of Social Sciences and Humanities, Department of Economics, Konya, TURKEY 


\section{Kurumsal Kalite ve Göçmen Gönderileri Arasındaki Asimetrik İlişki: Türkiye Üzerine Ampirik Bulgular}

\section{ÖZ}

Bu çalışma Türkiye'de kurumsal kalite endeksi ile göçmen gönderisi girişleri arasındaki asimetrik nedensellik ilişkisini 1985.1-2014.12 dönemi aylık veri ile araştırmayı amaçlamaktadır. Bu doğrultuda öncelikle ICRG tarafından yayınlanan 8 farklı kurumsal kalite göstergesinden hareketle kurumsal kalite endeksi oluşturulmuştur. Değişkenlerin durağanlık analizi iki yapısal kırılmalı Lee ve Strazicich (2003) birim kök testi yardımıla, nedensellik ilişkisinin varlığı ise Hatemi-J (2012) asimetrik nedensellik testi ile araştırılmıştır. Asimetrik nedensellik testinden elde edilen bulgular kurumsal kalite düzeyindeki iyileşmenin göçmen gönderilerinde bir artş̧a neden olmazken, kurumsal kalite düzeyinde ortaya çıkacak bir bozulmanın göçmen gönderileri üzerinde negatif bir etkiye neden olduğunu göstermektedir.

Anahtar Kelimeler Göçmen Gönderisi Girişleri, Kurumsal

Kalite, ICRG, Hatemi-J (2012)

Asimetrik Nedensellik Testi

JEL Kodu

F24, O53, C22

\section{Introduction}

In many developing countries, the flow of remittances has greatly accelerated and showed a rapid increase since the beginning of the 1990s. Remittances, which exceeded 600 billion USD all over the world in 2015, have been the second largest capital flow after foreign direct capital investments. What distinguishes remittances from other capital sources like foreign direct investment, portfolio investment, foreign aid, or borrowing is that they follow a more stable structure. Economic crises experienced on a regional or global scale affect all capital flows negatively, particularly foreign direct capital investments, while remittances are least affected by these crises. From this perspective, remittances are steady and continuous sources of income, and thus, are increasingly becoming important for developing countries. There is fairly extensive literature on the economic and social effects of remittances. Although there is no clear consensus, researchers generally argue that remittances decrease poverty, contribute to the development of human and physical capital, finance balance of payments deficits, and accelerate economic growth and development. On the other hand, the way remittances are utilized in the origin country determines the economic effects of remittances. When these remittances are directed towards productive investment areas, they affect economic growth and development positively. However, remittances have a negative impact on foreign trade balance as they increase 
consumption expenditures and import. Moreover, the increase in the amount of foreign currency flowing into a country increases the demand for the non-tradable goods like education, health, and construction. To meet the increasing demand, the production factors in the country are directed from trading areas to non-trading ones, which negatively affects the country's production and competitive power in foreign markets in the long run. This concept, which is defined as Dutch Disease in the literature, is the most discussed concept among the negative effects of remittances on the economy of the origin country. Furthermore, if domestic production channels do not support the increasing demands of the individuals receiving remittances for consumer goods, an inflationist effect may emerge in the medium and long run.

Many studies have so far examined the effect of remittances on income distribution, economic growth, economic development, and balance of foreign trade, but a limited number of studies have focused on the determinants of remittances. These studies generally focus on groups of countries. On the other hand, the literature on institutional quality concentrates on the relationship between institutional quality and economic growth. Thus, few studies in the literature examine the relationship between institutional quality and remittances considering one specific country. This study aims to fill the gap in the literature by examining the existence of the asymmetric causal relationship between remittance inflows and the institutional quality in Turkey. To this end, following the introduction section, the second section informs the readers about the determinants of remittances. Section 3 gives information about the data set, econometric methodology, and the empirical findings. The last section concludes the study.

\section{Determinants of Remittances}

The majority of the studies on the determinants of remittances examine whether remittances show similar tendencies to the other capital flows or which factors affect remittances. At this point, the most significant aspect that needs to be detected is the factors underlying remittances. The literature on the determinants of remittances hints that remittances are shaped by micro and macroeconomic factors (Docquier \& Rapoport, 2003). Microeconomic determinants are migrants' income, the level of education, marital status, age, gender, the duration of stay in the host country, and the socio-demographic features of migrant families (Agarwal \& Horowitz, 2002; Dorantes \& Pozo, 2006; Germenji, Beka \& Sarris, 2001). Macroeconomic determinants, on the other hand, refer to the macroeconomic variables which the host country and the origin 
country have. Interest rates, exchange rates, inflation, the level of wages, and financial development level of the country are some of these variables (Glytsos, 1997; Niimi, Caglar \& Schiff, 2010; Singh, 2012; Yuni, Omeje \& Asogwa, 2013). In addition to the listed micro and macroeconomic factors, migrants may send money to their home countries for personal reasons. Lucas and Stark (1985) argue that remittances are sent due to "pure altruism," "pure selfinterest" and "tempered altruism." The main reason why migrants send money to their families is that they worry about their families and relatives in the home country. The motive of selfsacrifice forms the basis of pure altruism. According to this proposition, migrants derive pleasure from the wealth of their relatives. Furthermore, Agarwal and Horowitz (2002) highlight that migrants increase the amount of the money they send to their families in the origin country to compensate for the negative shocks in the incomes of their relatives. Lowell and de la Garza (2000) maintain that altruistic motivations have a huge impact on the amount of money sent by the migrants in the US. According to the same study, families with children send 25 percent less money to their relatives in the home country compared to the families with no children. In addition to the motive of pure altruism, migrants make the capital transfer to their country of origin for pure self-interest. Personal interests like improving their social status in the countries of origin, keeping good relations with the relatives for inheritance, making investments for the future, and making a fortune account for the remittances sent due to pure self-interest motive (Aydas, Metin-Ozcan \& Neyapt1, 2005). Durand et al. (1996) argue that migrants send money to their home countries mainly to increase the physical and financial assets there. The results of the study on Tongan and Western Samoan migrants in Sydney revealed that migrants make capital transfer for their self-interests and particularly with the aim to accumulate assets and make investment (Brown, 1997). On the other hand, migrants who plan to return to their home countries in the future make the capital transfer to have real estate, financial assets, and social capital investments so that they can gain prestige and increase their political influence. According to a study conducted on Greek migrants in Germany, the amount of remittances sent by the migrants who consider returning to their home countries in the future is higher compared to the amount sent by the migrants who do not plan to return (Glytsos, 1988, 1997). Tempered altruism, on the other hand, is based on an agreement between migrants and the relatives in the origin country regarding mutual benefits (Ilahi \& Jafarey, 1999). This motive is established in a way 
that migrants transfer funds to their relatives in return for the maintenance of their assets in the home country.

The literature on the macroeconomic determinants of remittances uses economic indicators like inflation, economic growth, per capita income, exchange rate movements, the interest rate of the host country and the origin country, and employment rates. However, remittances are also affected by institutional indicators like democracy, human rights, government stability, accountability, the quality of the judicial system, and the structure of social and institutional tax system. The effect of macroeconomic factors on remittance is widely discussed in the literature, whereas a limited number of studies examine the relationship between remittance and institutional structure and institutional quality indicators. Catrinescu et al. (2009) maintain that in countries where the quality of political and economic institutions is high, remittances have a greater possibility of creating strong economic growth performance in the long run. This interaction obliges politicians to form an accountable and high-quality institutional structure. Rodrik (2004) states that monetary and fiscal policies that are based on effective property rights, rule of law and strong macroeconomic institutions are important factors for the investors who will come to a country. Thus, Rodrik (2004) argues that countries with the listed features receive more migrant income. Lartey and Mengova (2016) examined the effect of institutional quality on remittances using the data of 90 countries in the period between 1970 and 2012. The findings of the study revealed that institutional structure is among the important indicators of remittances in developing countries. Moreover, evidence shows that, although not very strong, there is a positive relationship between the quality of the legal system in a country and remittances.

Another important determinant of remittances is the transaction cost in the receiving country. An institutional structure which eases economic transactions and lowers transaction costs affects both the volume and the value of remittances. High transaction costs cause migrants either to give up sending money or to find unofficial ways for money transfer. When migrants choose unofficial ways to send money due to high transaction costs, rates of corruption increase. Abdih et al. (2012) assert that remittances affect the institutional quality in a country negatively by increasing corruption. According to Freund and Spatafore (2008), who state that cost of the transaction is the most significant determinant of remittances, a one-point decrease in transaction costs is associated with a 14 to 23 percent increase in remittances. In their study conducted in 84 
countries using the data for the period between 1990 and 2005, Bang et al. (2013) found that financial reforms increase the amount of remittances sent officially. Developments in the financial sector may make money transfer transactions easier and cheaper, which may encourage migrants to make more transfers. Aydas et al. (2005) also maintain that the developments in financial intermediation policy in Turkey accelerate money flow. On the other hand, Bettin et al. (2013) emphasize that the increase in financial development level affects remittances negatively and that a one-percent decrease in the level of financial development increases remittances at 0.9 percent. Giuliano and Arranz (2009) argue that migrants make more transfer of funds to remove the financial restrictions encountered by their relatives living in the countries where weak financial institutions exist.

Another institutional factor about remittances is the political instability in the country and not trusting the legal order. Aydas et al. (2005) conducted a study on Turkey, and they revealed that the military regime between 1965 and 1993 affected remittances negatively. If the institutional structure in a country can protect individual's property rights, remittances may become promising resources in economic development. North (1990) highlights the importance of institutions that guarantee property rights in the success of today's developed economies. According to Straubhaar (1986), trust in the security and liquidity of savings is more important than the probability of high profit. In addition to its boosting effect on the volume and efficiency of investment, the quality of institutions can play a role in economic growth and development through remittances. When the receiving country has high institutional quality, it facilitates the investment and fortune-building activities of the migrants in the recipient country, which affects remittances positively. On the other hand, when the weak institutional structure creates a negative investment climate, harms political stability, and leads to lack of trust; economic uncertainty increases and exerts a negative influence on remittances.

Directing migrants to portfolio investments with high risks may affect migrants' decisions as to whether they should invest their savings in the home or the host country. Thus, the presence of a stable institutional structure which supports foreign investments helps to attract remittances. Another factor that affects migrants' investment decisions is the difference between the interest rates in the home and host countries. Greater potential return to assets in the home country as opposed to the host country may encourage migrants to invest in the countries of origin and may, thus, stimulate remittances (IMF, 2005). 
Rodrik (2000) emphasizes the importance of five major market-supporting institutions, which are property rights, regulatory authorities, institutions for macroeconomic stability, institutions of social insurance, and institutions of conflict management. The first of these represents an institutional structure which ensures the implementation of agreements and property rights, decreases corruption, and encourages individuals to participate in economic activities and to make investment and innovation (Rodrik, Subramanian \& Trebbi, 2004). When the household receiving remittances have positive returns to their investments and have sufficient control over their assets, and when their property rights are protected, individuals give more importance to real and human capital investments and become more involved in the economy.

\section{Data, Econometric Methodology, and Empirical Findings}

This study aims to investigate the existence of asymmetric causal relationship between the institutional quality index and remittance inflows in Turkey. To this end, stationarity analysis of the institutional quality index (INSQUA) and remittance (REMIT) was conducted with the two structural breaks unit root test developed by Lee and Strazicich (2003), while the existence of asymmetric causality relationship was examined with Hatemi-J (2012) asymmetric causality test. The data set used in the empirical analysis covers the period between January 1985 and December 2014. The REMIT was compiled from Turkish Republic Central Bank Electronic Data Release System. INSQUA was formed through the Principal Components Method using eight different institutional quality indicators obtained from the PRS Group International Country Risk Guide (ICRG) database. These eight indicators are bureaucracy quality, corruption, democratic accountability, external conflict, government stability, internal conflict, investment profile, and law and order. The indicators with high values refer to low level of risk and high level of institutional quality.

Descriptive statistics of INSQUA and REMIT variables were given in Table 1. According to the results, remittance inflows in Turkey between January 1985 and December 2014 were about 185.7 million USD. During this period, remittance inflows were minimum 43 million USD and maximum 574 million USD. The mean of the institutional quality index in Turkey (INSQUA), which was formed with eight different indicators, is 8.22. In Turkey, for the specified period, the lowest and highest levels of institutional quality were 3.46 and 14.57, respectively. 
When the correlation coefficients of the variables given in Table 1 are examined, it is seen that there is a positive correlation between INSQUA and REMIT.

Table 1

Descriptive Statistics

\begin{tabular}{lcc}
\hline & $I N S Q U A$ & REMIT \\
\hline Mean & 8.222 & 185.7 \\
Std. Dev. & 2.456 & 115.1 \\
Maximum & 14.57 & 574.0 \\
Minimum & 3.460 & 43.00 \\
Jarque-Bera & $36.99^{*}$ & $3.156^{*}$ \\
\hline Correlation Matrix & INSQUA & REMIT \\
\hline INSQUA & - & 0.03 \\
REMIT & 0.03 & - \\
\hline * shows that the data are not normally distributed at the 1\% significance level.
\end{tabular}

The integration levels of the series are evaluated through unit root tests in time series analyses. The traditional unit root tests which are widely used in the literature like the Augmented Dickey-Fuller (hereafter ADF) (Dickey \& Fuller, 1979), Phillips-Perron (hereafter PP) (Phillips \& Perron, 1988), and KPSS (Kwiatkowski et al., 1992) are criticized for the reasons that they do not yield meaningful results with small samples and they do not take into consideration the structural breaks that could occur as a result of economic and political developments. Perron (1989) argues that when structural breaks are ignored, standard unit root tests yield misleading results about stationarity of the series (Perron, 1989: 1362). In this study, we used two structural breaks unit root test developed by Lee and Strazicich (2003) for the stationarity analysis of institutional quality index (INSQUA) and remittance inflows (REMIT) in Turkey.

Lee and Strazicich (2003) LM test is based on the data generation process given in Equation 1 (Lee \& Strazicich, 2003: 1082).

$$
y_{t}=\delta^{\prime} Z_{t}+e_{t} \quad e_{t}=\beta e_{t-1}+\varepsilon_{t}
$$

In the equations, $Z_{t}$ represents the external variable vector, and the null hypothesis of unit root is represented with $\beta=1$, while the alternative hypothesis is represented as $\beta<1$. $T_{B j}$ 
indicates the time of the break. Model A, which takes into account the break at level, can be defined as $Z_{t}=\left[1, t, D_{1 t}, D_{2 t}\right]^{\prime}$. When $j=1,2$ and $t \geq T_{B j}+1, D_{j t}=1$. In other cases, $D_{j t}=0$. Model $\mathrm{C}$, which takes two structural breaks at level and trend into account, can be shown as $Z_{t}=$ $\left[1, t, D_{1 t}, D_{2 t}, D T_{1 t}, D T_{2 t}\right]^{\prime}$. When $j=1,2$ and $t \geq T_{B j}+1, D T_{j t}=t-T_{B j}+1$. In other cases, $D T_{j t}=0$. The null and alternative hypotheses of Lee and Strazicich (2003) two structural breaks unit root test for Model C are given below (Lee \& Strazicich, 2003: 1083).

$H_{0}: y_{t}=\mu_{0}+d_{1} B_{1 t}+d_{2} B_{2 t}+y_{t-1}+\vartheta_{1 t}$

$H_{1}: y_{t}=\mu_{1}+\gamma t+d_{1} D_{1 t}+d_{2} D_{2 t}+\vartheta_{2 t}$

Lee and Strazicich (2003) critical table value and LM test statistics are compared to decide whether the null or the alternative hypothesis will be accepted in the presence of two structural breaks. When the calculated LM test statistics are higher than the critical value, the null hypothesis is accepted. In the presence of two structural breaks, it is decided that the series contains the unit root. In this respect, according to Lee and Strazicich (2003) test, if test statistics are greater than the critical values presented by Lee and Strazicich (2003), then the null hypothesis of a unit root is rejected (Lee \& Strazicich, 2003: 1086-1087).

Table 2

Lee and Strazicich (2003) Two Structural Breaks Unit Root Test Results

\begin{tabular}{|c|c|c|c|c|c|c|c|}
\hline \multirow[b]{2}{*}{ Variable } & \multicolumn{3}{|c|}{ Break in level (Model A) } & \multicolumn{4}{|c|}{ Break in level and trend (Model C) } \\
\hline & $\begin{array}{c}\text { Test } \\
\text { Statistics }\end{array}$ & $\begin{array}{l}\text { Fraction of } \\
\text { break point }\end{array}$ & $\begin{array}{c}\text { Break } \\
\text { date }\end{array}$ & $\begin{array}{c}\text { Test } \\
\text { Statistics }\end{array}$ & $\begin{array}{l}\text { Fraction of } \\
\text { break point }\end{array}$ & & $\begin{array}{c}\text { Break } \\
\text { date }\end{array}$ \\
\hline \multirow[t]{2}{*}{$I N S Q U A$} & \multirow{2}{*}{-2.823} & $\lambda_{1}: 0.18$ & 1990.5 & \multirow{2}{*}{-4.257} & $\lambda_{1}: 0.41$ & & 1997.5 \\
\hline & & $\lambda_{2}: 0.41$ & 1997.7 & & $\lambda_{2}: 0.51$ & & 2000.4 \\
\hline \multirow[t]{2}{*}{ REMIT } & \multirow{2}{*}{-2.424} & $\lambda_{1}: 0.36$ & 1995.12 & \multirow{2}{*}{-5.204} & $\lambda_{1}: 0.40$ & & 1997.3 \\
\hline & & $\lambda_{2}: 0.46$ & 1998.12 & & $\lambda_{2}: 0.54$ & & 2001.3 \\
\hline \multirow[t]{2}{*}{$\triangle I N S Q U A$} & \multirow{2}{*}{$-18.48 * * *$} & $\lambda_{1}: 0.31$ & & \multirow{2}{*}{$-19.71 * * *$} & $\lambda_{1}: 0.40$ & & \\
\hline & & $\lambda_{2}: 0.66$ & & & $\lambda_{2}: 0.47$ & & \\
\hline \multirow[t]{2}{*}{$\triangle R E M I T$} & \multirow{2}{*}{$-6.778 * * *$} & $\lambda_{1}: 0.37$ & & \multirow{2}{*}{$-11.212 * * *$} & $\lambda_{1}: 0.36$ & & \\
\hline & & $\lambda_{2}: 0.38$ & & & $\lambda_{2}: 0.41$ & & \\
\hline \multicolumn{3}{|c|}{ Critical values } & & \multicolumn{4}{|c|}{ Critical values } \\
\hline $1 \%$ & $5 \%$ & $10 \%$ & & & $1 \%$ & $5 \%$ & $10 \%$ \\
\hline \multirow[t]{3}{*}{-4.545} & -3.842 & -3.504 & & $\lambda_{1}: 0.20, \lambda_{2}: 0.40$ & -6.16 & -5.59 & -5.27 \\
\hline & & & & $\lambda_{1}: 0.40, \lambda_{2}: 0.60$ & -6.45 & -5.67 & -5.31 \\
\hline & & & & $\lambda_{1}: 0.60, \lambda_{2}: 0.80$ & -6.32 & -5.73 & -5.32 \\
\hline
\end{tabular}

Note. ${ }^{* * *}, * *$ and $*$ indicate rejection of the null hypothesis of the unit root at 1,5 , and 10 percent levels of significance, respectively. $\Delta$ is the first difference operator. As the series used in the study are monthly, maximum lag length was identified as 12 . 
The findings of Lee-Strazicich (2003) unit root test of Model A, which allows two structural breaks at the level, and Model $\mathrm{C}$, which takes into consideration the breaks both in level and trend, are given in Table 2. As the series used in the study are monthly, maximum lag length was identified as 12. The findings of Model A, which allows two breaks in level, indicate that the null hypothesis is accepted and both INSQUA and REMIT variables have unit root; in other words, they are not stationary. The findings of Model C, which takes into account two structural breaks in level and trend for INSQUA and REMIT variables, also show that both variables have unit root at level. According to the findings of Lee and Strazicich (2003) unit root test, it is determined that INSQUA and REMIT variables are not stationary at level according to both Model A and Model C. When the unit root test is re-applied to the first-differenced series, it is seen that unit root is eliminated and the series become stationary. The years 2000 and 2001 proposed by Lee and Strazicich (2003) two structural breaks unit root test correspond to the period of the economic crisis in Turkey.

Hatemi-J (2012) states that causal impact of positive shocks on the series is not the same as the causal impact of negative shocks. Hatemi-J (2012) examines the asymmetric causality relationship between the $y_{1 t}$ and $y_{2 t}$ series which are integrated at the same level following a random walk process (Hatemi-J, 2012: 448-449).

$$
\begin{gathered}
y_{1 t}=y_{1 t-1}+\varepsilon_{1 t}=y_{10}+\sum_{i=1}^{t} \varepsilon_{1 i} \\
y_{2 t}=y_{2 t-1}+\varepsilon_{2 t}=y_{20}+\sum_{i=1}^{t} \varepsilon_{2 i}
\end{gathered}
$$

In Equation 4 and 5, $t$ represents time dimension, while $y_{10}$ and $y_{20}$ denotes the constant terms that give the beginning value, and $\varepsilon_{1 i}$ and $\varepsilon_{2 i}$ represents the error term. As $\varepsilon_{1 i}=\varepsilon_{1 i}^{+}+\varepsilon_{1 i}^{-}$ and $\varepsilon_{2 i}=\varepsilon_{2 i}^{+}+\varepsilon_{2 i}^{-}$, Hatemi-J (2012) defines positive shocks as $\varepsilon_{1 i}^{+}=\max \left(\varepsilon_{1 i}, 0\right)$ and $\varepsilon_{2 i}^{+}=$ $\max \left(\varepsilon_{2 i}, 0\right)$ and negative shocks as $\varepsilon_{1 i}^{-}=\min \left(\varepsilon_{1 i}, 0\right)$ and $\varepsilon_{2 i}^{-}=\min \left(\varepsilon_{2 i}, 0\right)$. Thus, Equation 4 and 5 were reorganized and Equation 6 and 7 were derived (Hatemi-J, 2012: 449).

$$
y_{1 t}=y_{1 t-1}+\varepsilon_{1 t}=y_{10}+\sum_{i=1}^{t} \varepsilon_{1 i}^{+}+\sum_{i=1}^{t} \varepsilon_{1 i}^{-}
$$


$y_{2 t}=y_{2 t-1}+\varepsilon_{2 t}=y_{20}+\sum_{i=1}^{t} \varepsilon_{2 i}^{+}+\sum_{i=1}^{t} \varepsilon_{2 i}^{-}$

As $y_{t}^{+}=\left(y_{1 t}^{+}, y_{2 i}^{+}\right)$and $y_{t}^{-}=\left(y_{1 t}^{-}, y_{2 i}^{-}\right)$, the $\operatorname{VAR}(\mathrm{p})$ models in Equation 8 and 9 were estimated respectively to examine the causality relationship between the positive and negative cumulative shocks (Hatemi-J et al., 2016: 2304).

$y_{t}^{+}=v+A_{1} y_{t-1}^{+}+\cdots .+A_{p} y_{t-1}^{+}+u_{t}^{+}$
$y_{t}^{-}=v+A_{1} y_{t-1}^{-}+\cdots .+A_{p} y_{t-1}^{-}+u_{t}^{-}$

HJC information criterion was used for optimal lag order (p) selection in the VAR models in Equations 8 and 9. After determining the optimal lag length, the null hypothesis of no causality $\left(H_{0}: C \beta=0\right)$ was examined with the Wald test (Hatemi-J, 2012: 450).

$$
\text { Wald }=(C \beta)^{\prime}\left[C\left(\left(Z^{\prime} Z\right)^{-1} \otimes S_{U}\right) C^{\prime}\right]^{-1}(C \beta)
$$

To decide whether there are causal relationships between variables, test statistics are compared with bootstrap critical values. If the LM test statistics are higher than bootstrap critical values, the null hypothesis is rejected and there is causality between variables (Hatemi-J, 2012: 451).

Table 3

Hatemi-J (2012) Asymmetric Causality Test Results

\begin{tabular}{|c|c|c|c|c|}
\hline \multirow{2}{*}{ Null Hypothesis } & \multirow[b]{2}{*}{ Statistics } & \multicolumn{3}{|c|}{ Critical Values } \\
\hline & & $1 \%$ & $5 \%$ & $10 \%$ \\
\hline$I N S Q U A^{+} \neq>R E M I T^{+}$ & 0.236 & 8.155 & 3.680 & 2.363 \\
\hline INSQUA $A^{-} \neq>R E M I T^{-}$ & $22.78 * * *$ & 15.721 & 11.135 & 8.448 \\
\hline$I N S Q U A^{+} \neq>R E M I T^{-}$ & 1.439 & 8.925 & 4.247 & 2.686 \\
\hline$I N S Q U A^{-} \neq>R E M I T^{+}$ & 1.213 & 17.042 & 7.563 & 4.777 \\
\hline $\operatorname{REMIT}^{+} \neq>I N S Q U A^{+}$ & 0.473 & 9.059 & 4.053 & 2.598 \\
\hline$R E M I T^{-} \neq>I N S Q U A^{-}$ & 2.573 & 19.380 & 11.695 & 8.735 \\
\hline $\operatorname{REMIT}^{+} \neq>I N S Q U A^{-}$ & 1.439 & 8.925 & 4.247 & 2.686 \\
\hline$R_{E M I T}{ }^{-} \neq>I N S Q U A^{+}$ & 0.636 & 8.733 & 4.073 & 2.623 \\
\hline
\end{tabular}

Note. The notation $X \neq>Y$ means that $\mathrm{X}$ does not cause $\mathrm{Y}$.

$* * *, * *$ and * indicate statistical significance at confidence level 1,5 and $10 \%$, respectively. In this study, AIC is used to determine lag length, and the maximum lag length was taken as 4 . Bootstrap critical values were based on 10000 replications. 
Table 3 shows the results of Hatemi-J (2012) test, which was conducted to identify the presence of an asymmetric causality relationship between the INSQUA and REMIT variables. According to the findings in Table 3, seven of the eight null hypotheses of no asymmetric causality relationship between these two variables were not rejected. Among the null hypotheses, the one which suggests that a negative shock in INSQUA does not cause a negative shock in REMIT, was rejected. This finding means that a negative shock in institutional quality level in Turkey has negative effects on remittance inflows. Thus, while deterioration in institutional quality in Turkey leads to a decrease in the remittance inflows, an increase in institutional quality in Turkey does not lead to an increase in remittances.

\section{Conclusion}

The significant increase in the volume of remittances sent by migrants to their home countries is seen as a new source for economic development, and this topic has considerably attracted the attention of researchers. The literature on remittances generally focuses on its effects on the economic performance. Some researchers, on the other hand, study the determinants of these remittances. There are various factors which affect the decision of the immigrants to send money to the relatives in their home countries. According to the literature, some migrants decide to send money to their relatives due to the feelings of self-sacrifice, personal interests, or mutual interests, while some studies argue that micro and macroeconomic factors may also be playing a role in this decision. Macroeconomic factors are generally related to the economic performance and institutional structure of the country which the immigrant migrated to and currently lives in. The importance of institutions and remittances in economic development is highlighted in many research studies in the field of economics. A majority of the studies on institutional quality and economic development revealed that countries with a strong institutional structure attract more foreign capital. Thus, the level of institutional quality may be considered to be among the determinants of remittances. A positive relationship between high-quality institutional structure and remittances forces policymakers to improve the institutional quality indicators to attract more remittances. Therefore, it can be argued that there is a bilateral causality between institutional quality and remittance inflows.

This study examines the asymmetric causality relationship between the remittance inflows and the level of institutional quality in Turkey. The asymmetric causality relationship between 
remittances to Turkey (REMIT) and institutional quality index (INSQUA) obtained through the principal components method from eight different institutional indicators was examined with Hatemi-J (2012) causality test. In the study, first, the integration levels of the series were determined by the two structural breaks unit root test developed by Lee and Strazicich (2003). Then, the asymmetric causality test developed by Hatemi-J (2012) was used to detect the presence of an asymmetric relationship between the series. According to the findings, in Turkey, the improvement in the level of institutional quality does not cause an increase in remittance inflows, whereas negative shocks in the level of institutional quality lead to a negative shock on remittances. Thus, it can be said that the improvement in institutional quality does not bring about a change in the decision of immigrants to make capital transfer. However, deterioration in institutional structure has a negative effect on remittances. From this perspective, it can be argued that negative changes in the level of institutional quality influence remittances and there is an asymmetric causality relationship between the series.

\section{References}

Abdih, Y., Chami, R., Dagher, J., \& Montiel, P. (2012). Remittances and institutions: are remittances a curse? World Development, 40(4), 657-666.

Agarwal, R., \& Horowitz, A. (2002). Are international remittances altruism or insurance? evidence from Guyana using multiple-migrant households. World Development, 30(11), 2033-2044.

Aydas, K., Ozcan, M., \& Neyapti, B. (2005). Determinants of workers' remittances: the case of Turkey. Emerging Markets Finance and Trade, 41(3), 53-69.

Bang, J., Mitra. A., \& Wunnava. P. (2013). Financial liberalization and remittances: recent longitudinal evidence. IZA DP No. 7497.

Bettin, G., Presbitero, A. F., \& Spatafora, N. (2013). Remittances and vulnerability in developing countries, Working Paper, International Monetary Fund.

Brown, R. (1997). Estimating remittance functions for pacific island migrants. World Development, 25(4), 613-626.

Catrinescu, N., Leon-Ledesma, M., Piracha, M., \& Quillin, B. (2009). Remittances, institutions and economic growth. World Development, 37(1), 81-92. 
Dickey, D., \& Fuller, W. (1979). Distribution of the estimators for autoregressive time series with a unit root, Journal of the American Statistical Association, 74, 427-431.

Docquier, F., \& Rapoport, H. (2003). Remittances and inequality: a dynamic migration model, IZA Discussion Paper No. 808, Institute for the Study of Labor, Bonn.

Dorantes, C. A., \& Pozo, S. (2006). Migration, remittances and male and female employment patterns, American Economic Review, 96(2), 222-226.

Durand, J., Kandel, W., Parrado, E. A., \& Massey, D. S. (1996). International migration and development in Mexican communities, Demography, 33(2), 249-264.

Freund, C., \& Spatafora, N. (2008). Remittances, transaction costs and informality, Journal of Development Economics, 86(2), 356-366.

Germenji, E., Beka, I., \& Sarris, A. (2001). Estimating remittance functions for rural-based Albanian emigrants, Working Paper, ACE research project, P97-8158-R: Microeconomic Analysis of Farm Restructuring in Central and Eastern Europe.

Giuliano, P., \& Ruiz-Arranz, M. (2009). Remittances, financial development, and growth, Journal of Development Economics, 90(1), 144-152.

Glytsos, N. P. (1988). Remittances in temporary migration: A theoretical model and its testing with the Greek-German experience, Weltwirtschaftliches Anrhiv, 124(3), 524-549.

Glytsos, N. P. (1997). Remitting behaviour of temporary and permanent migrants: the case of Greeks in Germany and Australia, Labour, 11(3), 409-435.

Hatemi-J, A. (2012). Asymmetric causality tests with an application, Empirical Economics, 43, 447-456.

Hatemi-J, A., Ajmi, A., El Montasser, G., Inglesi-Lotz, R., \& Gupta, R. (2016). Research output and economic growth in G7 countries: New evidence from asymmetric panel causality testing, Applied Economics, 48(24), 2301-2308.

Ilahi, N., \& Jafarey, S. (1999). Guestworker migration, remittances and the extended family: evidence from Pakistan, Journal of Development Economics, 2, 485-512.

IMF (2005). World Economic Outlook: Globalization and External Imbalances, International Monetary Fund, (April), Washington DC.

Kwiatkowski, D., Phillips, P. C. B., Schmidt, P., \& Shin, Y. (1992). Testing the null of stationary against the alternative of a unit root: how sure are we that economic time series have a unit root? Journal of Econometrics, 54(1), 159-178. 
Lartey, E. K. K., \& Mengova, E. (2016). Does institutional quality in developing countries affect remittances? The Journal of Developing Areas, 50(1), 59-76.

Lee, J., \& Strazicich, M. C. (2003). Minimum Lagrange multiplier unit root test with two structural breaks. The Review of Economics and Statistics, 85(4), 1082-1089.

Lowell, B. L., \& De La Garza, R. O. (2000). The developmental role of remittances in US Latino communities and in Latin American countries, A Final Project Report, Inter-American Dialogue.

Lucas, R. E. B., \& Stark, O. (1985). Motivations to remit: Evidence from Botswana. Journal of Political Economy, 93(5), 901-918.

Niimi, Y., Caglar, O., \& Schiff, M. (2010). Remittances and the brain drain: Skilled migrants do remit less. Annales d'Economie et de Statistique, (97-98), 123-141.

North, D. C. (1990). Institutions, Institutional Change and Economic Performance. Cambridge: Cambridge University Press.

Perron, P. (1989). The great crash, the oil price shock and the unit root hypothesis. Econometrica, 57, 1361-1401.

Phillips, P., \& Perron, P. (1988). Testing for a unit root in time series regression. Biometrica, 75, 335-346.

Rodrik, D. (2000). Institutions for high-quality growth: What they are and how to acquire them? Studies in Comparative International Development, 35(3), 3-31.

Rodrik, D. (2004). Getting institutions right: Institutions and economic performance, CESifo DICE report: Journal for Institutional Comparions; the international platform of LudwingMaximilians University's Center for Economic Studies and the Ifo Institue, 2(2).

Rodrik, D., Subramanian, A., \& Trebbi, F. (2004). Institutions rule: The primacy of institutions over geography and integration in economic development, Journal of Economic Growth, $9(2), 131-165$.

Singh, R. J. (2012). From Shock Absorber to Shock Transmitter: Determinants of Remittances in Sub-Saharan Africa, In Migration and Remittances during the Global Crisis and Beyond, edited by Ibrahim Sirkeci, Jeffery H. Cohen, \& Dilip Ratha, World Bank Publications, 349-357.

Straubhaar, T. (1986). The determinants of worker's remittances: The case of Turkey, Weltwirtschaftliches Archiv, 122(4), 728-740. 
Yuni, D., Omeje, A., \& Asogwa, H. (2013). Determinants of remittance: Panel evidence from selected countries in Africa, Journal of Economics and Sustainable Development, 4(20), $52-57$ 